\title{
Targeted Toxins for the Treatment of Prostate Cancer
}

\author{
Philipp Wolf ${ }^{1,2}$ \\ 1 Department of Urology, Medical Center, University of Freiburg, 79106 Freiburg, Germany; \\ philipp.wolf@uniklinik-freiburg.de; Tel.: +49-761-270-28921 \\ 2 Faculty of Medicine, University of Freiburg, 79106 Freiburg, Germany
}

check for

updates

Citation: Wolf, P. Targeted Toxins for the Treatment of Prostate Cancer. Biomedicines 2021, 9, 986. https:/ / doi.org/10.3390/biomedicines9080986

Academic Editor: Chiara Brignole

Received: 16 July 2021

Accepted: 7 August 2021

Published: 9 August 2021

Publisher's Note: MDPI stays neutral with regard to jurisdictional claims in published maps and institutional affiliations.

Copyright: (C) 2021 by the author. Licensee MDPI, Basel, Switzerland. This article is an open access article distributed under the terms and conditions of the Creative Commons Attribution (CC BY) license (https:// creativecommons.org/licenses/by/ $4.0 /)$.

\begin{abstract}
Prostate cancer is the second most common cancer and the fifth leading cause of cancer deaths worldwide. Despite improvements in diagnosis and treatment, new treatment options are urgently needed for advanced stages of the disease. Targeted toxins are chemical conjugates or fully recombinant proteins consisting of a binding domain directed against a target antigen on the surface of cancer cells and a toxin domain, which is transported into the cell for the induction of apoptosis. In the last decades, targeted toxins against prostate cancer have been developed. Several challenges, however, became apparent that prevented their direct clinical use. They comprise immunogenicity, low target antigen binding, endosomal entrapment, and lysosomal/proteasomal degradation of the targeted toxins. Moreover, their efficacy is impaired by prostate tumors, which are marked by a dense microenvironment, low target antigen expression, and apoptosis resistance. In this review, current findings in the development of targeted toxins against prostate cancer in view of effective targeting, reduction of immunogenicity, improvement of intracellular trafficking, and overcoming apoptosis resistance are discussed. There are promising approaches that should lead to the clinical use of targeted toxins as therapeutic alternatives for advanced prostate cancer in the future.
\end{abstract}

Keywords: prostate cancer; targeted toxins; targeting; immunogenicity; intracellular trafficking; resistance

\section{Prostate Cancer}

The fight against prostate cancer (PC) is a major challenge. Improvements in diagnosis and treatment in recent years have led to reduced or at least stable mortality rates in most countries [1]. Nevertheless, with almost 1.4 million estimated new cases and 375,000 deaths PC remains the second most frequent cancer and the fifth leading cause of cancer deaths in men worldwide [2]. Primary tumors can be successfully treated by surgery or radiation. Curative treatment, however, is no longer possible in advanced stages and many patients develop castration resistant PC (CRPC) after androgen deprivation therapy. The median survival of patients with metastatic CRPC ranges between 15 and 36 months $[3,4]$. Therefore, new treatment options are urgently needed for advanced stages of the disease.

\section{Targeted Toxins}

Recognizing that naturally occurring bacterial, plant or human toxins can effectively kill human cells, including tumor cells, targeted toxins have been developed as therapeutic alternatives for numerous tumor entities [5]. Targeted toxins are chemical conjugates or fully recombinant proteins, which consist of two main parts: a binding domain and a toxin domain. The binding domain ensures specific targeting of antigens on the surface of tumor cells. When the binding domain is an antibody, antibody fragment, or cytokine, targeted toxins are also called immunotoxins. When the binding domain is a ligand, growth factor, or hormone, they can also refer to as fusion (protein) toxins. Ribosome-inactivating proteins (RIPs) are preferred toxins for the generation of targeted toxins. They come from bacteria or plants, have enzymatic activity, and irreversibly inhibit protein biosynthesis in eukaryotic cells [6]. Bacterial RIPs have evolved under evolutionary pressure as virulence 
factors to effectively damage host cells. Prominent examples comprise, e.g., Diphteria toxin (DT) from Corynebacterium diphtheriae [7] or Pseudomonas Exotoxin A (PE, ETA) from Pseudomonas aeruginosa [8]. Plant toxins evolved to defend against pests and comprise Ricin A from Ricinus communis or Saporin from Saponaria officinalis [9].

Some RIPs, like DT, PE, or Ricin A, naturally contain binding domains against cell surface structures that are widely distributed on eukaryotic cells [10]. This creates a broad spectrum of host cells that can be attacked by the toxins. Exchange of the natural binding domains against antibodies or ligands are therefore done in order to achieve specific binding to target antigens on the surface of cancer cells [11]. Some RIPs also comprise sequences for the toxin translocation via eukaryotic membranes that can be used for the generation of targeted toxins for guidance of the toxin domain into the cytosol [6].

In general, targeted toxins exert their cytotoxicity as shown in Figure 1. After systemic application they are transported via the bloodstream to the tumor and bind with help of their binding domain to antigens on the surface of the tumor cells [12]. Then the targeted toxin/antigen complex is taken up into the cells by receptor-mediated endocytosis. For DT-based targeted toxins, the acidic $\mathrm{pH}$ in the endosomes causes conformational changes of the translocation domain, resulting in a large channel that allows release of the toxin domain into the cytoplasm [7]. The translocation domain of PE undergoes a conformational change, which makes a furin-cleavable motif accessible. The protease furin cleaves the toxic domain from the binding domain. After cleavage the binding and toxin domains are still connected by a disulfide bond, which encompasses the furin cleavage site. There is evidence that there is an unfolding event, possibly under the influence of chaperones, which leads to a surface exposure of the disulfide bond, which is finally reduced, presumably by protein-disulfide-isomerases [8,13]. PE and Ricin A are transported via the trans-Golgi network retrogradely into the Endoplasmatic Reticulum (ER). There, they use the ER-associated protein degradation (ERAD) pathway for the transport of misfolded cellular proteins for ubiquitination and subsequent proteasomal degradation to enter the cytosol [14]. Once there, the toxins inhibit the cellular protein biosynthesis by ADP-ribosylation of the eukaryotic elongation factor 2 (eEF-2) on the ribosomes (PE, DT) $[8,15]$, or by rRNA N-glycosidase activity to depurinate a critical adenine, which results in the inability of the ribosome to bind to eEF-2 (Saporin, Ricin A) [16,17]. The inhibition of protein biosynthesis results in an induction of the intrinsic apoptotic pathway and finally death of the tumor cells.

Molecular mechanisms that lead to the induction of apoptosis after inhibition of protein biosynthesis are not yet fully understood and appear to be toxin- and cell-dependent. In PC cells, PE-based targeted toxins have been shown to degrade anti-apoptotic Bcl-2 proteins, specifically Mcl-1 and Bcl-2A1 [18,19]. This results in an activation of the proapoptotic effectors Bak and Bax followed by cytochrome $\mathrm{C}$ release from the mitochondria and induction of apoptosis (Figure 2). In addition, protein biosynthesis inhibition can directly induce mitochondrial stress, lipid oxidation, DNA damage, and thus apoptosis. In addition, MAPK/JNK activation might be involved, leading to an upregulation of proapoptotic effector proteins, downregulation of anti-apoptotic proteins, and triggering of mitochondrial stress (rev. in [20]). 


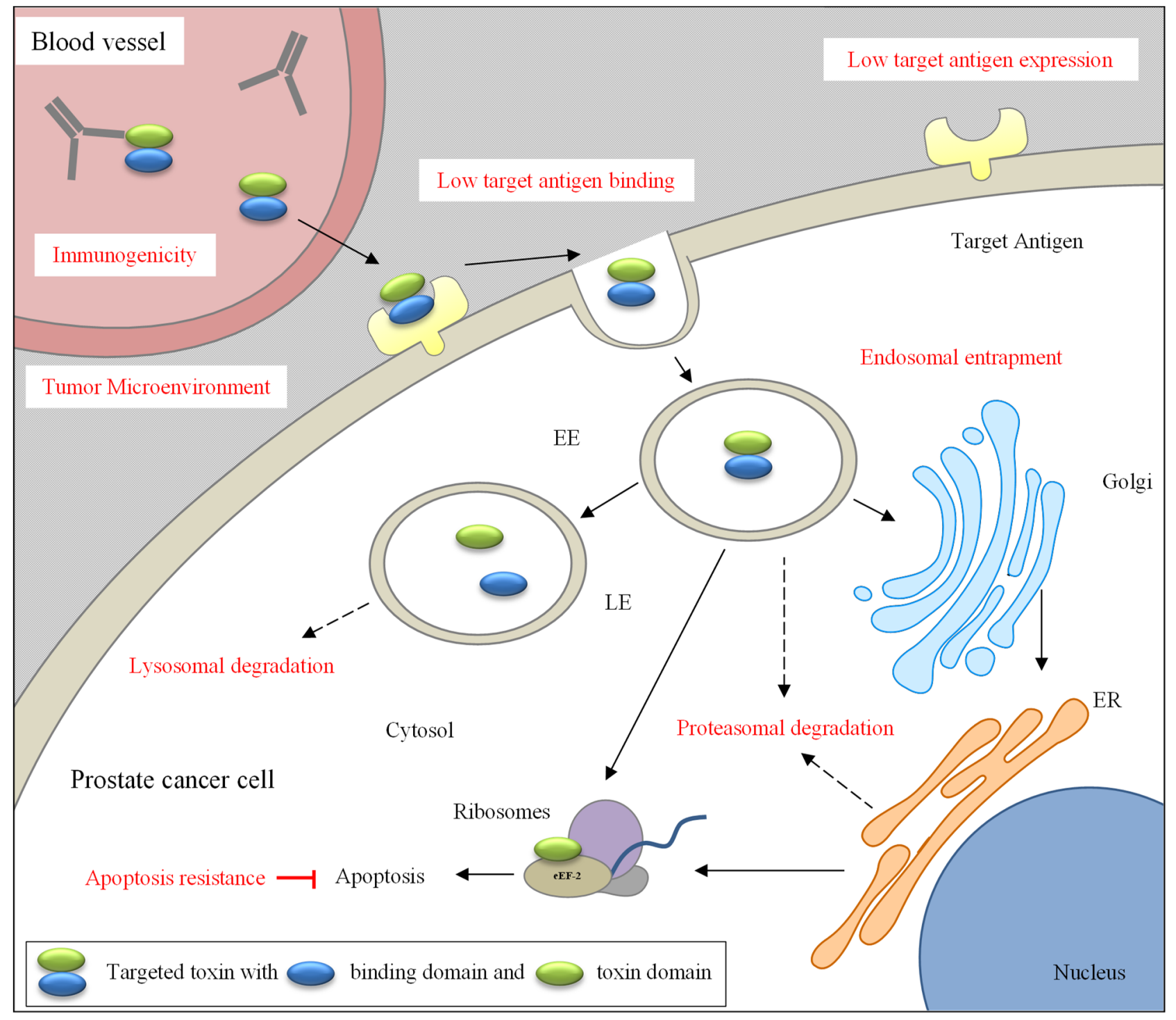

Figure 1. Intoxication of prostate cancer cells with targeted toxins and hurdles that might impair their efficacy. After systemic application targeted toxins are transported via the bloodstream to the tumor sites. They bind to antigens on the tumor cell surface and are internalized into early endosomes. After cleavage from the binding domain, the toxin domain is transported directly or via the Golgi network and the endoplasmatic recticulum into the cytosol. When RIP toxin domains are used, there is an inhibition of protein biosynthesis on the ribosomes with subsequent induction of apoptosis. Hurdles that might impair the efficacy of the targeted toxins are shown in red and comprise immunogenicity and low antigen binding of the targeted toxins, endosomal entrapment as well as lysosomal/proteasomal degradation during trafficking. Tumor cells can attenuate cytotoxicity by a dense tumor microenvironment, low antigen expression and apoptosis resistance. Abbreviations: EE, early endosomes; ER, endoplasmatic reticulum; LE, late endosomes. 


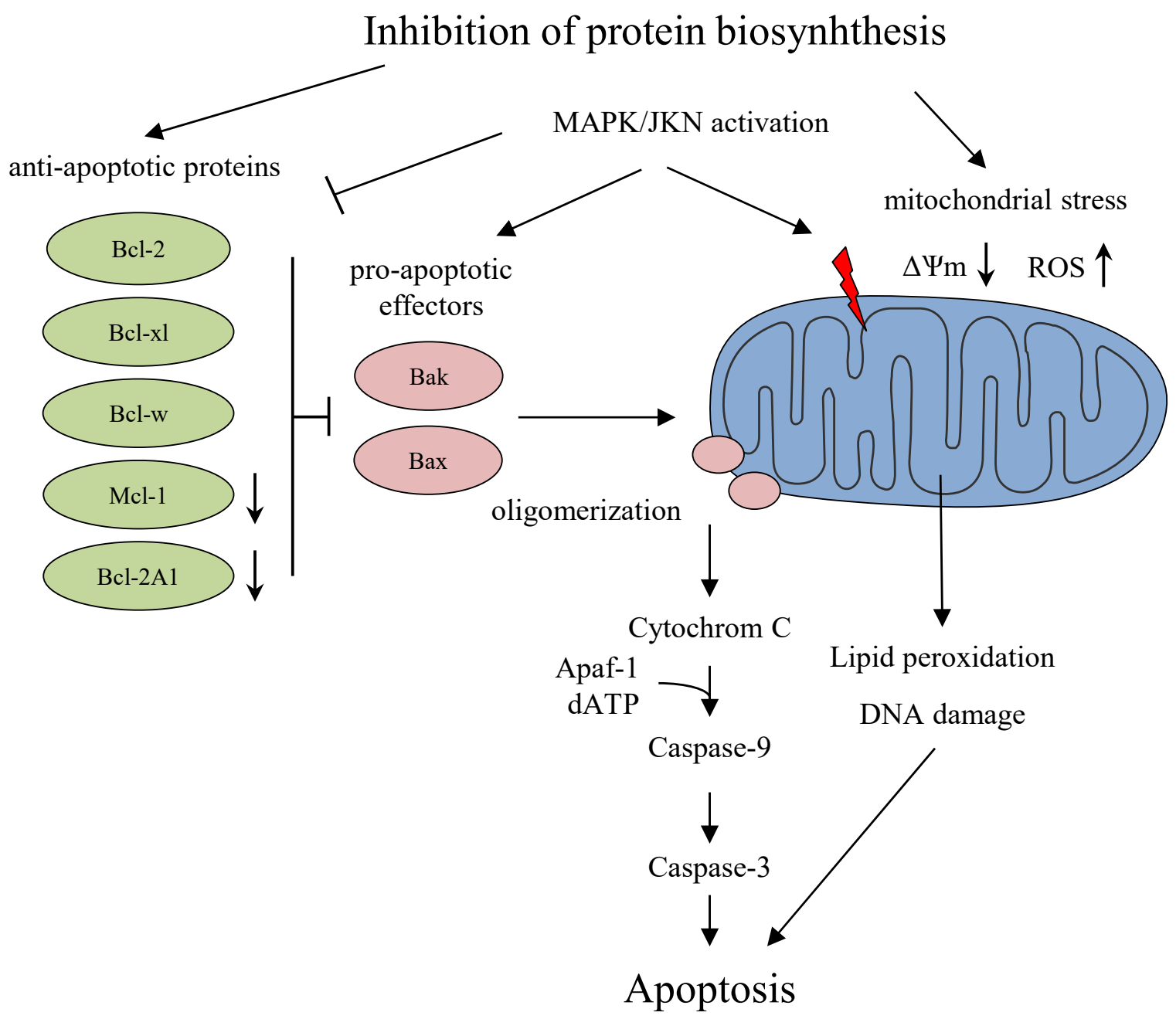

Figure 2. Proposed mechanisms by which targeted toxins induce apoptosis in cancer cells after inhibition of protein biosynthesis. $\uparrow$ upregulation; $\downarrow$, downregulation.

\section{Targeted Toxins in the Clinic}

Three targeted toxins were approved by the FDA for cancer treatment until today: Denileukin diftitox $\left(\mathrm{Ontak}^{\circledR}\right)$, consisting of IL2 as binding and DT as toxin domain, for the treatment of cutaneous T cell lymphoma (CTCL) in 1999 [21], Moxetumomab pasudotox (Lumoxiti ${ }^{\circledR}$ ), consisting of an anti-CD22 antibody fragment and PE38 from Pseudomonas Exotoxin A, for the treatment of hairy cell leukemia (HCL) [22], and Tagraxofusp-erzs (Elzonris ${ }^{\circledR}$ ), consisting of IL3 and DT, for the treatment of blastic plasmacytoid dentritic cell neoplasm (BPDCN) [23], both in 2018. Various targeted toxins against solid tumors are currently tested in clinical trials, but have not been approved yet (ref. in [24]).

In summary, targeted toxins are very potent drugs for cancer therapy that specifically target cancer cells and have a high antitumor activity. Constitutive internalization of targeted toxins after antigen binding results in an intracellular enrichment. Moreover, due to their enzymatic activity targeted toxins elicit a much higher cytotoxicity than antibodies or inhibitors, which only show a stoichiometric one to one binding to their targets and act by blocking of signaling pathways in the target cells.

Our review focuses on the preclinical development and optimization of targeted toxins for the treatment of PC. For this, PubMed database was used to identify studies on targeted toxins against prostate cancer (main keywords: prostate (cancer), (targeted) toxins, immunotoxins). 


\section{Targeted Toxins against Prostate Cancer}

Generally, PC is regarded as a suitable target for targeted toxin therapy, because (a) PC cells are generally slowly growing and express well described target antigens, (b) PC metastases predominantly involve lymph nodes and bones, locations that are readily accessible to circulating targeted toxins, and (c) the prostate-specific antigen (PSA) serum marker is established for the early detection of metastases and for monitoring the therapeutic efficacy.

In the last years, different targeted toxins were generated for the treatment of PC and were successfully tested in view of binding, internalization and cytotoxicity on PC cells representing different advanced stages of the disease (Table 1). Different antigens were targeted that are present as transmembrane proteins on the PC cell surface, not shed into circulation and internalized after targeted toxin binding. The most prominent examples are the epidermal growth factor receptor (EGFR) and the prostate specific membrane antigen (PSMA). Both show enhanced expression in advanced metastatic and castration-resistant stages of PC and are correlated with worse prognosis and poor clinical outcome [25-28].

Targeted toxins have not yet been used in clinical trials against PC, because the treatment of solid tumors provides challenges that are not easy to solve. The challenges comprise immunogenicity, low antigen binding, endosomal entrapment, and lysosomal/proteasomal degradation of the targeted toxins. Moreover, tumor cells might reduce their efficacy by formation of a dense tumor microenvironment, low target antigen expression, and apoptosis resistance (Figure 1).

In the following sections solutions for overcoming these challenges in view of effective targeting, reduction of immunogenicity, improvement of intracellular trafficking, and overcoming resistance are discussed (Table 2). 
Table 1. Preclinical studies with targeted toxins against prostate cancer.

\begin{tabular}{|c|c|c|c|c|c|}
\hline Antigen & Targeted Toxin & Binding Domain & Toxin Domain & Enhanced Efficacy/Safety by & Ref. \\
\hline CD44 & IM7-saporin & anti-CD44 mAb (clone IM7) & Saporin & combination with PCI & [29] \\
\hline CDPD1 & ch25A11-Sap & anti-CDCP1 mAb 25A11 & Saporin & & [30] \\
\hline EGFR & $\begin{array}{l}\text { scFv2112-ETA' (from cetuximab) } \\
\text { scFv1711-ETA' (from panitumumab) }\end{array}$ & anti-EGFR scFv & ETA $^{\prime}$ & & {$[32]$} \\
\hline FGF & bFGF-SAP & bFGF & saporin & & [34] \\
\hline Her2 & scFv(FRP5)-ETA & anti-HER2 scFv & ETA & & [35] \\
\hline \multirow[t]{3}{*}{ IL13R } & IL-13PE & human IL-13 & PE38 & $\begin{array}{l}\text { human binding domain, enhancing target } \\
\text { antigen expression, intratumoral injection }\end{array}$ & [36] \\
\hline & IL13-PE38QQR & human IL-13 & PE38QQR & $\begin{array}{l}\text { human binding domain, enhancing target } \\
\text { antigen expression }\end{array}$ & [37] \\
\hline & IL13-PE38QQR & human IL-13 & PE38QQR & human binding domain & [38] \\
\hline IL4R & hIL4-PE4E & human IL-4 & PE mutant & human binding domain & [40] \\
\hline LHRH & LHRH-RNase A conjugate & LHRH & bovine RNaseA & human binding domain & [41] \\
\hline p185 erbB-2 & AR209 & anti-p185 erbB-2 scFv e23Fv & PE38KDEL & & [42] \\
\hline \multirow[t]{7}{*}{ PSMA } & JVM-PE24X7 & anti-PSMA sd Ab & PE24X7 & de-immunized toxin domain & [43] \\
\hline & hD7-1(VL-VH)-PE40 & anti-PSMA scFv & PE40 & combination with ABT-737 & [19] \\
\hline & $\begin{array}{c}\text { hD7-1(VL-VH)-PE40 } \\
\text { hD7-1(VL-VH)-PE24 } \\
\text { hD7-1(VL-VH)-PE24mut }\end{array}$ & humanized anti- PSMA scFv & $\begin{array}{c}\text { PE40 } \\
\text { PE24 } \\
\text { PE24mut }\end{array}$ & de-immunized toxin domains & [44] \\
\hline & D7(VL-VH)-PE40 & humanized anti-PSMA scFv & PE40 & combination with ABT-737 & [18] \\
\hline & immunocasp-3 & anti-PSMA scFv J591 & rev caspase-3 & human binding and toxin domain & [45] \\
\hline & hD7-1(VL-VH)-PE40 & anti-PSMA scFv & PE40 & combination with docetaxel & [46] \\
\hline & J591PE & anti-PSMA scFv (J591) & PE38QQR & combination with pan-PI3K inhibitor & [47] \\
\hline
\end{tabular}


Table 1. Cont.

\begin{tabular}{|c|c|c|c|c|c|}
\hline Antigen & Targeted Toxin & Binding Domain & Toxin Domain & Enhanced Efficacy/Safety by & Ref. \\
\hline & A-dmDT390-scfbDb(PSMA) & anti-PSMA sdAb J591 & truncated diphtheria toxin (DT) & & [48] \\
\hline & $\begin{array}{c}\text { D7-VH(Yol)VL-PE40 } \\
\text { D7-VH(GS)VL-PE40 } \\
\text { His D7-VH(GS)VL-PE40 } \\
\text { D7-VL(GS)VH-PE40 } \\
\text { His-D7-VL(GS)VH-PE40 }\end{array}$ & anti-PSMA scFv & PE40 & $\begin{array}{l}\text { enhanced affinity by changing } \mathrm{scFv} \\
\text { domain orientation }\end{array}$ & [49] \\
\hline & hJ591-SAZAP & hJ591 & saporin & humanized $\mathrm{mAb}$ as binding domain & {$[50]$} \\
\hline & A5-PE40 & anti-PSMA scFv A5 & PE40 & & [52] \\
\hline & A5-PE40 & anti-PSMA scFv A5 & PE40 & & [53] \\
\hline & E6-dgA & anti-PSMA mAb E6 & ricin A chain & & [54] \\
\hline & J591-smpt-nRTA & $\begin{array}{c}\text { anti-PSMA mAbs J591 } \\
\text { PEQ226.5 } \\
\text { PM2P079.1 }\end{array}$ & RTA, native orrecombinant & & [55] \\
\hline Tf & Tf-SapTf-A RCA & transferrin & Saporin or Ricin A & $\begin{array}{l}\text { human binding domain, combination with } \\
\text { monensin and chloroquine }\end{array}$ & [56] \\
\hline
\end{tabular}

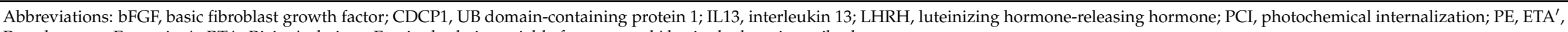
Pseudomonas Exotoxin A; RTA, Ricin A chain; scFv, single chain variable fragment; sdAb, single domain antibody. 
Table 2. Strategies to optimize the efficacy of targeted toxins against prostate cancer.

\begin{tabular}{|c|c|c|c|}
\hline & Challenges & Solutions & Ref. \\
\hline \multicolumn{4}{|l|}{ Effective Targeting } \\
\hline Surmounting the TME & $\begin{array}{l}\text { TME prevents extravasation } \\
\text { and tumor penetration of } \\
\text { targeted toxins }\end{array}$ & $\begin{array}{l}\text { Surmounting the TME by } \\
\text { - intratumoral injection of the } \\
\text { targeted toxins } \\
\text { - pre-damage of tumor masses }\end{array}$ & {$[36,39,46]$} \\
\hline \multirow[t]{2}{*}{$\begin{array}{c}\text { Enhancing tumor } \\
\text { penetration and affinity }\end{array}$} & $\begin{array}{l}\text { Large size of targeted toxins } \\
\text { prevents tumor pentration }\end{array}$ & $\begin{array}{l}\text { Reducing the size of the binding domain } \\
\text { Reducing the size of the toxin domain }\end{array}$ & {$[31,44]$} \\
\hline & $\begin{array}{l}\text { Targeted toxins have low } \\
\text { binding affinity }\end{array}$ & $\begin{array}{l}\text { Enhancing affinity by changing the } \\
\text { arrangement of the functional domains of } \\
\text { a targeted toxin }\end{array}$ & [49] \\
\hline $\begin{array}{l}\text { Enhancing target } \\
\text { antigen expression }\end{array}$ & $\begin{array}{l}\text { Low target antigen expression } \\
\text { on the PC cells }\end{array}$ & $\begin{array}{l}\text { Enhancing target antigen expression by } \\
\text { - gene transfer } \\
\text { - drugs }\end{array}$ & {$[36,37]$} \\
\hline $\begin{array}{c}\text { Reducing } \\
\text { on-target/off-tumor toxicities }\end{array}$ & $\begin{array}{l}\text { Targeted toxins might harm } \\
\text { normal cells that express the } \\
\text { target antigen }\end{array}$ & $\begin{array}{l}\text { Reducing on-target/off-tumor toxicity by } \\
\text { - intratumoral injection of the targeted } \\
\text { toxins } \\
\text { - local activation of the targeted toxins }\end{array}$ & {$[29,33,36,39]$} \\
\hline \multicolumn{4}{|l|}{$\begin{array}{l}\text { Reduction of } \\
\text { immunogenicity }\end{array}$} \\
\hline $\begin{array}{l}\text { Reducing the } \\
\text { immunogenicity of the } \\
\text { binding domain }\end{array}$ & $\begin{array}{l}\text { Targeted toxins with } \\
\text { non-human binding domain } \\
\text { are immunogenic in } \\
\text { PC patients }\end{array}$ & $\begin{array}{l}\text { Reducing immunogenicity by } \\
\text { - humanization of antibody fragments } \\
\text { - use of human ligands }\end{array}$ & {$[18,34,36-40,44,50,56]$} \\
\hline $\begin{array}{l}\text { Reducing the } \\
\text { immunogenicity of the } \\
\text { toxin domain }\end{array}$ & $\begin{array}{l}\text { Targeted toxins with } \\
\text { non-human toxin domain are } \\
\text { immunogenic in PC patients }\end{array}$ & $\begin{array}{l}\text { Reducing immunogenicity by } \\
\text { - de-immunization } \\
\text { - use of human toxins }\end{array}$ & {$[31,41,44,45]$} \\
\hline $\begin{array}{l}\text { Improvement of } \\
\text { intracellular trafficking }\end{array}$ & $\begin{array}{l}\text { lysosomal and proteasomal } \\
\text { degradation of the } \\
\text { targeted toxins }\end{array}$ & $\begin{array}{l}\text { Enhancing cytosolic release by } \\
\text { - addition of drugs } \\
\text { - photochemical internalization }\end{array}$ & {$[29,33]$} \\
\hline $\begin{array}{l}\text { Overcoming apoptotic } \\
\text { resistance }\end{array}$ & $\begin{array}{l}\text { apoptosis resistance of } \\
\text { PC cells }\end{array}$ & $\begin{array}{l}\text { Enhancing sensitivity to apoptosis by } \\
\text { combination with } \\
\text { - BH3 mimetics } \\
\text { - chemotherapy } \\
\text { - kinase inhibitors }\end{array}$ & {$[18,19,46,47]$} \\
\hline
\end{tabular}

\section{Effective Targeting}

\subsection{Challenges}

Major obstacles for the treatment of prostate tumors with targeted toxins are an elevated tumor interstitial fluid pressure and a TME, which is marked by stromal cells, extracellular matrix, defective blood, and lymphatic vessels [57]. They prevent an effective extravasation and tumor penetration of macromolecules like targeted toxins following systemic application [58].

\subsection{Solutions for Effective Targeting}

\subsubsection{Surmounting the TME}

To surmount the TME, a focal targeted toxin treatment of local prostate tumors may be considered. In a study of Husain and colleagues repeated intratumoral injections of the targeted toxin IL4-Ctx consisting of the IL4 ligand and the PE variant PE38KDEL as toxin domain into s.c. growing LNCaP or DU145 tumors in nude mice was found to be 
more effective compared to intraperitoneal or intravenous injections. Complete remissions in all animals bearing DU145 tumors were recorded after treatment with high doses of $500 \mu \mathrm{g} / \mathrm{kg}$ IL4-Ctx [39]. In another study, growth of PC-3 tumors expressing IL13 was significantly inhibited by intratumoral injection of the targeted toxin IL13-PE [36]. The effective treatment of PC by intratumoral application of toxin conjugates was confirmed in a recent study. Rogers and colleagues used urea-based small PSMA inhibitors for the targeted delivery of the PE35 toxin domain into PC cells. Intratumoral application of the conjugate into mice bearing PSMA expressing PC-3 tumors resulted in a $>50 \%$ average reduction in tumor size after two weeks and a $>90 \%$ reduction in PSA levels in animals with LNCaP xenografts [59]. Like other focal treatment modalities of PC, such as high intensity focal ultrasound, focal laser ablation, photodynamic therapy, or focal cryotherapy, focal targeted toxin treatment could be considered suitable for patients placed between active surveillance and whole-gland extirpative therapy [60]. Independent from prostate volume, a PSA value of $<15 \mathrm{ng} / \mathrm{mL}$, clinical stage T1c-T2a, Gleason score $3+3$ or $3+4$, and a life expectancy of $>10$ years are recommended as inclusion criteria for a focal therapy [61]. Stereotactic injection of the targeted toxins would allow to increase intratumoral availability and systemic toxicities could be diminished or avoided. Moreover, since focal therapy would require considerably fewer targeted toxin doses than systemic therapy, costs for targeted toxin manufacturing could be reduced. It must be taken, however, into account that prostate tumors are often multifocal and treatment of only the index lesions could not be sufficient to control the disease for a long time [62].

Pretreatment of prostate tumors with drugs that damage solid tumor masses and the TME could help systemic applicated targeted toxins to reach the tumor cells better (rev. in [63]). For example, taxanes were found to decompress blood vessels, lower interstitial fluid pressure and reduce the density of different solid tumors [64-66]. We found a 7.5- to 19-fold increased cytotoxicity of the anti-PSMA targeted toxin D7(VL-VH)PE40 after combination with docetaxel on LNCaP and C4-2 cells. Moreover, an enhanced in vivo antitumor activity of the targeted toxin was demonstrated after pretreatment with docetaxel in a PC SCID mouse xenograft model [46]. Further studies must show whether the high efficacy of the combination therapy was due to a pre-damage of the tumors by chemotherapy and due to increased accessibility of the tumor cells for the targeted toxin.

\subsubsection{Enhancing Tumor Penetration and Affinity}

Further strategies to enhance the efficacy of targeted toxins against solid tumors are to reduce their size to facilitate tumor penetration and to optimize their binding affinity. For first generation targeted toxins against PC, full-length IgG molecules, like anti-CD44, anti-UB domain-containing protein 1 (CDCP1), or anti-EGFR mAbs were used [29,30,33]. Macromolecules like IgG with about $150 \mathrm{kDa}$ in weight, however, can only penetrate tumor masses poorly and can be taken up by Fc receptor expressing cells $[67,68]$. This overall leads to a reduced number of therapeutically active targeted toxins on the tumor side. For enhanced tumor penetration, targeted toxins of newer generations are therefore preferably constructed using antibody fragments, such as single-chain variable fragments (scFv) or single-domain antibodies (sdAb) with a molecular mass of only about 30 or $12-15 \mathrm{kDa}$, respectively $[48,69]$.

A reduction in size for an enhanced tumor penetration can also be achieved by deleting parts of the toxin domains. For example, we generated the anti-PSMA targeted toxin hD71(VL-VH)-PE24 containing a truncated PE24 toxin domain with $24 \mathrm{kDa}$ in size and the targeted toxin hD7-1(VL-VH)-PE40 with the $40 \mathrm{kDa}$ toxin domain as counterpart. With hD7-1(VL-VH)-PE24 IC 50 values of $82 \mathrm{pM}$ and $24 \mathrm{pM}$ on LNCaP and C4-2 cells, respectively, were reached after $72 \mathrm{~h}$ incubation. For hD7-1(VL-VH)-PE40 similar $\mathrm{IC}_{50}$ values of $25 \mathrm{pM}$ and $6 \mathrm{pM}$ were determined [44]. This example proves that size reduction of a toxin domain can be done without or only marginally impairment of cytotoxicity. Further experiments will show, if the PE24 based targeted toxin shows enhanced tumor penetration in vivo. 
A reduction in size, however, can also lead to a significant change in the pharmacokinetics of a targeted toxin. A molecular weight of $<60 \mathrm{kDa}$ can result in a fast renal clearance and a reduced serum half-life and consequently requires repeated or continuous systemic administration in the patient. The attachment of polyethylene glycol (PEGylation) is one method to increase the molecular weight and the plasma half-life of targeted toxins [70].

$\mathrm{ScFv}$ have generally lower affinity to the target antigen in comparison to their parental full length IgG due to monovalent binding and absence of stabilizing constant regions [71,72]. $\mathrm{ScFv}$ with affinities in the low $\mathrm{nM}$ range are generally discussed most suitable for the construction of targeted toxins, because $\mathrm{scFv}$ with lower affinity failed to significantly accumulate in tumors, whereas $\mathrm{scFv}$ with higher affinities showed a limited tumor penetration $[73,74]$. Changing the order of the variable domains of the heavy $(\mathrm{VH})$ and light chain (VL) of a scFv in a targeted toxin can also lead to changes in binding affinity. We constructed two targeted toxins against PC consisting of the anti-PSMA scFv D7 as binding domain and PE40 as toxin domain with different VH-VL orientations. Whereas for the targeted toxin with $\mathrm{VH}-\mathrm{VL}$ orientation a $\mathrm{K}_{\mathrm{d}}$ value of $57.7 \mathrm{nM}$ was calculated on C4-2 cells, its counterpart with the $\mathrm{scFv}$ in $\mathrm{VL}-\mathrm{VH}$ orientation showed a an about 3-fold enhanced affinity $\left(\mathrm{K}_{\mathrm{d}}=18.3 \mathrm{nM}\right)[49]$.

\subsubsection{Enhancing Target Antigen Expression}

Generally, targeted toxins show higher cytotoxicity in cells with a higher target antigen expression than with a lower one [32,35]. Therefore, increasing the antigen expression in PC cells was examined as a strategy to enhance the sensitivity of targeted toxins [37]. In a study of Gonzalez-Moreno and colleagues, PC-3 cells were transfected with the gene of the peptide adrenomedullin (AM). An upregulation of about 100 genes was found after transfection involved in regulating cell cycle arrest, apoptosis, cytoskeleton, cell adhesion, extracellular matrix, immune function and transcription, including the IL-13 receptor subunit a2 (IL-13Ra2) [75]. Treatment of PC-3 cells with the AM peptide also led to an enhanced expression of IL-13Ra2 protein. After five days of incubation of the AM transfected PC-3 cells with the targeted toxin IL13-PE, consisting of IL13 and the PE38 toxin domain, an $\mathrm{IC}_{50}$ value of $5 \mathrm{ng} / \mathrm{mL}$ was reached in AM-treated PC-3 cells compared to an $\mathrm{IC}_{50}$ value of $>1000 \mathrm{ng} / \mathrm{mL}$ in PC-3 mock cells. Based on these results, AM was discussed as an enhancer of IL13 expression and sensitizer for IL13-PE therapy of PC [36]. In another study only low cytotoxicity with the targeted toxin IL13-PE38QQR was found in DU145 cells expressing IL-13R [37]. Transfection of the cells with the IL$13 R \alpha 2$ subunit, which is an essential component for IL-13 binding and internalization [76], however, increased the affinity of the targeted toxin to IL-13 and enhanced its cytotoxicity and in vivo antitumor activity. Based on these data, sensitizing tumor cells for targeted toxin treatment by upregulation of IL-13 via gene transfer or by use of steroids or cytokines was discussed [37].

Taken together, there has to be a good balance between size and affinity of a targeted toxin and antigen expression on the tumor cells in order to achieve an optimal targeting.

\subsubsection{Reducing On-Target/Off-Tumor Toxicities}

A main challenge, that is generally found in targeted therapies against cancer, is the presence of target antigens on normal cells which prevents the targeted toxins from acting in a tumor-specific manner. This means that targeted toxins might also damage such cells and that so-called on-target/off-tumor toxicities have to be expected in the clinic. For example, EGFR is widely distributed in human organs, including brain, heart, liver, skin, kidney, bone, breast, and lung [77]. Therefore, combination of anti-EGFR targeted toxins with other targeted agents agents or local activation by light might help to reduce on target/off-tumor side effects in future [33]. Besides the prostate, PSMA is expressed in the small intestine and in proximal tubules of normal kidneys and highest expression is found in the salivary glands [78,79]. Therefore, damage of these tissues could be a concern, when targeted toxins are used against PSMA. Indeed, xerostomia was found to be dose- 
limiting in anti-PSMA radioligand therapy. Interestingly, however, this coud be based on the preferential accumulation of the electronegatively charged radioligands in the salivary glands [80]. Xerostomia might, therefore, be radioligand specific and on-target/off-tumor toxicities in salivary glands might not be a feature of future targeted toxin therapies for PC.

\section{Reduction of Immunogenicity \\ 6.1. Challenges}

Targeted toxins are artificial proteins that can be immunogenic in the patient, if they are not of human origin. Immunogenicity has to be given special consideration in the treatment of patients with PC, since their immune system is usually not compromised by disease or pretreatment.

Studies with targeted toxins against hematological malignancies demonstrated that immunogenic reactions can occur already after one therapy cycle and leads to T-cell dependent and B-cell mediated formation of anti-drug antibodies (ADA) (rev. in [81]). ADAs can be either binding or neutralizing antibodies that alter the pharmacokinetics and reduce the efficacy of the targeted toxins. Moreover, they can induce adverse side effects like infusion reactions and hypersensitivity/anaphylactic reactions, which might be dose-limiting and result in discontinuation of treatment [82,83]. It is therefore necessary to reduce the immunogenicity of targeted toxins on both sides of the binding domains and of the toxin domains to increase patients' safety.

\subsection{Solutions for Reduction of Immunogenicity}

\subsubsection{Reducing the Immunogenicity of the Binding Domain}

Many full-length monoclonal antibodies (mAbs) were generated via hybridoma techniques in mice. Therefore, targeted toxins containing such mAbs are expected to evoke immunogenic reactions in the patients [84]. Since many human anti-mouse antibodies react with the $F_{c}$ region of the mAbs, the use of antibody fragments that do not have an $\mathrm{Fc}$ region, like $\mathrm{scFv}$ or $\mathrm{dsFv}$, are preferred for the construction of targeted toxins with reduced immunogenicity. Immunogenicity of antibody fragments can be reduced by 'humanization', a genetic engineering process during that the complementarity determining regions (CDRs) are transferred to human variable region frameworks [85]. Moreover, humanized antibodies and antibody fragments can be directly generated by immunization of transgenic animals with introduced human immunoglobulin loci [86].

It is important that the specific antigen binding is not lost during the humanization process and that the cytotoxicity of targeted toxins, into which the humanized antibody or antibody fragments are incorporated, is still sufficient. In studies with PE-based targeted toxins containing murine or humanized anti-PSMA scFv as binding domains, specific binding to PSMA expressing LNCaP and C4-2 cells with comparable binding constants and cytotoxicity for both variants were described $[18,44,46]$.

Another way to reduce the immunogenicity of the binding domain is to use human ligands. For the construction of targeted toxins against PC, e.g., the epidermal growth factor (EGF), the basic fibroblastic growth factor (bFGF), the interleukins-4 (IL-4) and -13 (IL-13), the lutenizing hormone-releasing hormone (LHRH), or human transferrin were used that are not expected to produce immunogenic reactions in the patients (Table 1). The corresponding targeted toxins showed comparable cytotoxicities with $\mathrm{IC}_{50}$ values in the low $\mathrm{nM}$ range against PC cells compared to those constructed with antibody fragments [31,34,36-39,41,56].

\subsubsection{Reducing the Immunogenicity of the Toxin Domain}

Toxin domains elicit also immunogenic reactions in patients, when they originate from bacteria or plants. Besides the type I RIP protein Bouganin from Bougainvillea spectabilis, from which the de-immunized variant deBouganin exists [87], PE is a toxin, which was de-immunized by deletion of the translocation domain with exception of the furin clavage site [88] and by mutation of immunodominant B and T cell epitopes of domain III [89]. 
Targeted toxins containing the de-immunized PE domain showed reduced immunogenicity in preclinical and clinical trials [81]. Mutation of the B-cell epitopes, however, resulted in new T cell epitopes in the PE domain at the same time [89].

We have generated the targeted toxin EGF-PE24mut, consisting of the EGF ligand as binding and PE24mut as de-immunized toxin domain, and found a 6.1- to 11.9-fold reduced affinity ( $\mathrm{Kd}=26.6-36.9 \mathrm{nM})$ on LNCaP, C4-2, or PC-3 cells compared to the EGF ligand alone. However, it also had a 4-6.5-fold higher affinity compared to the targeted toxin EGF-PE40 containing the parental PE40 domain [31]. We presume that the smaller PE24mut domain resulted in less steric inhibition of the EGF ligand than the larger PE40 domain. The cytotoxicity of EGF-PE24mut on the PC cells, however, was about 11- to 120-fold lower than that of EGF-PE40. This can be traced back to the fact that the translocation domain of PE is deleted in parts in the PE24mut domain, so that its intracellular trafficking might be impaired. Our example shows that de-immunization of the toxin domain can lead to a higher affinity of a targeted toxin. On the other side, efficacy of targeted toxins can be diminished, e.g., when domains are affected by the de-immunization process, which are important for the function of the targeted toxin.

Minimizing the immunogenicity of the toxin domains can also be done by PEGylation $[82,90]$. PEG can mask immunogenic epitopes and is thought to be not immunogenic. However, in different studies anti-PEG antibodies have been detected in patients treated with PEGylated proteins, suggesting that PEG might be immunogenic itself and possibly enhance the immune responses to therapeutic agents [91].

The incorporation of human toxin domains into targeted toxins also helps to enhance safety, because they are not expected to be immunogenic in patients. In the last years, various targeted toxins against different tumor entities were generated containing the pro-apoptotic Bcl-2 family members Bax, Bak, or Bid/tBid, caspases, granzymes, endonucleases, RNases, or kinases (rev. in [92]). Meng and colleagues generated the targeted toxin immunocasp-3 consisting of the anti-PSMA scFv J591 as binding domain and human caspase- 3 as toxin domain against PC. LNCaP cells that were co-incubated with immunocasp-3 secreting Jurkat cells were effectively killed. Moreover, tumor growth inhibition and enhanced survival was reached in mice with subcutaneous growing LNCaP tumors treated with lipofectamine-encapsuled immunocasp-3 or with the immunocasp-3 secreting Jurkat cells. Since human toxins lack a translocation domain with a cleavage site for cytosolic delivery, it was necessary to insert the furin-cleavable domain of Diphteria toxin between the two functional domains [45].

Targeted toxins containing human toxins are generally found to have lower cytotoxicity and antitumor activity compared to targeted toxins containing RIPs. The reason might be that human toxins can be inhibited by endogenous inhibitors in the cytosol. For example, caspase 3 can be inhibited by the X-linked inhibitor of apoptosis protein (XIAP) [93], RNaseA can be inhibited by ribonuclease inhibitors [94] and granzyme B can be blocked by the serin protease inhibitor B9 (serpin B9) [95].

Despite significant progress in the de-immunization of targeted toxins, there is still need for future research on how they can be administered in a truly safe manner in patients, including those with PC, without causing undesired immune responses.

\section{Improvement of Intracellular Trafficking}

\subsection{Challenges}

Prerequisite for a well-functioning targeted toxin is that the toxin domain is cleaved from the binding domain in the endosomes of target cells after internalization and that it reaches its site of action (ribosomes) in the cytosol. There is a risk of endosomal entrapment and lysosomal or proteasomal degradation of the toxin domain on its way through different cellular compartments (Figure 1). 


\subsection{Solutions to Improve Intracellular Trafficking}

To avoid degradation, agents can be added that cause a release of the toxin domains directly from the endosomes into the cytosol. These agents can be lysomotropic amines, carboxylic ionophores, or calcium channel antagonists, which temporarily weaken the membrane integrity, or cell penetrating peptides of different origin (rev. in [96]). An alternative is the use of glycosylated triterpenoids, like saponins, which are thought to associate with endo-/lysosomal membranes and mediate a $\mathrm{pH}$ value dependent delivery of the toxin domain into the cytosol [97].

In different studies with targeted toxin against PC, the Photochemical Internalization (PCI) technology was used to avoid lysosomal degradation and to enhance cytosolic release $[29,33]$. In PCI, photosensitizers that accumulate together with the targeted toxins in the endo-/lysosomes induce the formation of singlet oxygen after irradiation with light [98]. This leads to a damage of the endolysosomal membranes and release of the toxin domain into the cytosol. In a study of Bostad and colleagues, addition of the photosensitizer TPCS 2 (Amphinex) enhanced the cytosolic release of the targeted toxin IM7-saporin, consisting of an anti CD44 mAb as binding domain and saporin as toxin domain. As a result, the cytotoxic effects of the targeted toxin were enhanced in different CD44 expressing cancer cell lines, including the PC cell line DU145 [29]. In another study, synergistic cytotoxic effects were evoked in DU145 cells by PCI using the anti-EGFR targeted toxin cetuximabsaporin in combination with the photosensitizer $\mathrm{TPPS}_{2 \mathrm{a}}$ [33]. The use of PCI ensures that only cells, which are in the focus of the light source, are affected by the targeted toxin, thus avoiding on target/off-tumor side effects. The drawback of PCI, however, is that PC cannot be treated systemically with this method. The future scope of PCI-assisted targeted toxin therapy is therefore in the treatment of local prostate tumors or lymph nodes, which can be reached, e.g., via light emitting laser fibers.

\section{Overcoming Apoptosis Resistance}

\subsection{Challenges}

Resistance mechanisms against targeted toxins comprise a decrease in target antigen expression, an impaired intracellular trafficking, and apoptotic resistance in the tumor cells [99]. As mentioned above, a decrease in antigen expression could be overcome by increasing antigen expression via gene therapy or addition of drugs [36,37]. Intracellular trafficking of targeted toxins against PC can be enhanced by adding drugs or using PCI for enhanced cytosolic release $[29,33]$.

Resistance against apoptosis, a typical hallmark of cancer, is based on an upregulation of anti-apoptotic Bcl-2 proteins (Bcl-2, Bcl-xl, Mcl-1) in PC cells [100] Interestingly, the proapoptotic members Bax and Bak are omnipresent in all tumor stages and mutations in these proteins that could affect their function are very rare $[100,101]$. Different combinatorial approaches with the aim of restoring sensitivity to apoptosis for effective target toxin therapy were therefore examined in PC cells $[18,19,46,47]$.

\subsection{Solutions to Overcome Apoptosis Resistance}

The cytotoxicity of PE is based on the inhibition of protein biosynthesis of the target cells. Especially the expression of the anti-apoptotic proteins Mcl-1 and Bcl-2A1 is affected, because they have only short half-lives from a few minutes to a few hours due to constitutive protein turnover through poly-ubiquitination and proteasomal degradation [19]. We combined low doses of the anti-PSMA targeted toxin hD7(VL-VH)-PE40 with ABT-737, a BAD-like mimetic that inhibits the anti-apoptotic protein Bcl-2, Bcl-xl, and Bcl-w. The combination led to specific and synergistic cytotoxic effects on PSMA-expressing LNCaP and C4-2 cells and to a significantly prolonged survival of mice bearing C4-2 xenografts based on tumor growth inhibition [19]. Synergistic in vitro and in vivo effects were also found by combination of the targeted toxin D7(VL-VH)-PE40 with docetaxel chemotherapy [46]. Since docetaxel is known to sensitize PC cells for apoptosis by p53 activation and by altering the phosphorylation of $\mathrm{Bcl}-2$ proteins, it is conceivable that it reduced the threshold for 
the induction of apoptosis by the targeted toxin. Baiz and colleagues generated a targeted toxin consisting of the anti-PSMA scFv J591 as binding and PE38QQR as toxin domain, called J591-PE. Combination of J591-PE with the pan-PI3K inhibitor ZSTK474 induced apoptosis in LNCaP and C4-2 cells. This was based on a reduction of Mcl-1 expression by the targeted toxin and on a dephosphorylation of BAD by the inhibitor that resulted in an enhanced inhibition of Bcl-2, Bcl-xl, and Bcl-w [47].

\section{Conclusions}

About three decades have passed since the generation of the first targeted toxins against cancer. Targeted toxins against hematological malignancies have already received clinical approval. Numerous others against solid tumors are currently still in early clinical trials, because it has taken a long time to develop them to the point where they can be tested safely for efficacy. Preclinical studies of targeted toxins against PC have shown that they have very high cytotoxic activity and that there are opportunities to overcome challenges to efficacy and safety. The use of targeted toxins in the context of a personalized medical approach that takes into account, for example, target antigen expression and possible resistance mechanisms in the tumor, could improve the treatment options for patients with advanced PC in the future.

Funding: This work was supported by a grant of the German Research Foundation (Grant No. WO 2178/2-1). The article processing charge was funded by the Baden-Wuerttemberg Ministry of Science, Research and Art and the University of Freiburg in the funding programme Open Access Publishing.

Institutional Review Board Statement: Not applicable.

Informed Consent Statement: Not applicable.

Conflicts of Interest: The author declares no conflict of interest.

\section{References}

1. Culp, M.B.; Soerjomataram, I.; Efstathiou, J.A.; Bray, F.; Jemal, A. Recent Global Patterns in Prostate Cancer Incidence and Mortality Rates. Eur. Urol. 2019, 77, 38-52. [CrossRef]

2. Sung, H.; Ferlay, J.; Siegel, R.L.; Laversanne, M.; Soerjomataram, I.; Jemal, A.; Bray, F. Global Cancer Statistics 2020: GLOBOCAN Estimates of Incidence and Mortality Worldwide for 36 Cancers in 185 Countries. CA A Cancer J. Clin. 2021, 71, 209-249. [CrossRef]

3. Litwin, M.S.; Tan, H.J. The diagnosis and treatment of prostate cancer: A review. JAMA 2017, 317, 2532-2542. [CrossRef] [PubMed]

4. Crawford, E.D.; Petrylak, D.; Sartor, O. Navigating the evolving therapeutic landscape in advanced prostate cancer. Urol. Oncol. Semin. Orig. Investig. 2017, 35, S1-S13. [CrossRef]

5. Shilova, O.; Shramova, E.; Proshkina, G.; Deyev, S. Natural and Designed Toxins for Precise Therapy: Modern Approaches in Experimental Oncology. Int. J. Mol. Sci. 2021, 22, 4975. [CrossRef]

6. Walsh, M.J.; Dodd, J.E.; Hautbergue, G.M. Ribosome-inactivating proteins: Potent poisons and molecular tools. Virulence 2013, 4, 774-784. [CrossRef]

7. Shafiee, F.; Aucoin, M.G.; Jahanian-Najafabadi, A. Targeted Diphtheria Toxin-Based Therapy: A Review Article. Front. Microbiol. 2019, 10, 2340. [CrossRef]

8. Michalska, M.; Wolf, P. Pseudomonas Exotoxin A: Optimized by evolution for effective killing. Front. Microbiol. 2015, 6, 963. [CrossRef]

9. Fabbrini, M.S.; Katayama, M.; Nakase, I.; Vago, R. Plant Ribosome-Inactivating Proteins: Progesses, Challenges and Biotechnological Applications (and a Few Digressions). Toxins 2017, 9, 314. [CrossRef]

10. Shi, W.-W.; Mak, A.N.-S.; Wong, K.-B.; Shaw, P.-C. Structures and Ribosomal Interaction of Ribosome-Inactivating Proteins. Molecules 2016, 21, 1588. [CrossRef]

11. Allahyari, H.; Heidari, S.; Ghamgosha, M.; Saffarian, P.; Amani, J. Immunotoxin: A new tool for cancer therapy. Tumor Biol. 2017, 39. [CrossRef]

12. Pak, Y.; Pastan, I.; Kreitman, R.J.; Lee, B. Effect of Antigen Shedding on Targeted Delivery of Immunotoxins in Solid Tumors from a Mathematical Model. PLoS ONE 2014, 9, e110716. [CrossRef] [PubMed]

13. Blum, J.; Fiani, M.; Stahl, P. Proteolytic cleavage of ricin A chain in endosomal vesicles. Evidence for the action of endosomal proteases at both neutral and acidic pH. J. Biol. Chem. 1991, 266, 22091-22095. [CrossRef]

14. Nowakowska-Gołacka, J.; Sominka, H.; Sowa-Rogozińska, N.; Słomińska-Wojewódzka, M. Toxins Utilize the Endoplasmic Reticulum-Associated Protein Degradation Pathway in Their Intoxication Process. Int. J. Mol. Sci. 2019, 20, 1307. [CrossRef] [PubMed] 
15. Murphy, J.R. Mechanism of Diphtheria Toxin Catalytic Domain Delivery to the Eukaryotic Cell Cytosol and the Cellular Factors that Directly Participate in the Process. Toxins 2011, 3, 294-308. [CrossRef]

16. Bagga, S.; Seth, D.; Batra, J.K. The Cytotoxic Activity of Ribosome-inactivating Protein Saporin-6 Is Attributed to Its rRNA N-Glycosidase and Internucleosomal DNA Fragmentation Activities. J. Biol. Chem. 2003, 278, 4813-4820. [CrossRef]

17. Grela, P.; Szajwaj, M.; Horbowicz-Drożdżal, P.; Tchórzewski, M. How ricin damages the ribosome. Toxins 2019, 11, 241. [CrossRef]

18. Noll, T.; Schultze-Seemann, S.; Kuckuck, I.; Michalska, M.; Wolf, P. Synergistic cytotoxicity of a prostate cancer-specific immunotoxin in combination with the BH3 mimetic ABT-737. Cancer Immunol. Immunother. 2017, 67, 413-422. [CrossRef]

19. Masilamani, A.P.; Dettmer-Monaco, V.; Monaco, G.; Cathomen, T.; Kuckuck, I.; Schultze-Seemann, S.; Huber, N.; Wolf, P. An Anti-PSMA Immunotoxin Reduces Mcl-1 and Bcl2A1 and Specifically Induces in Combination with the BAD-Like BH3 Mimetic ABT-737 Apoptosis in Prostate Cancer Cells. Cancers 2020, 12, 1648. [CrossRef]

20. Narayanan, S.; Surendranath, K.; Bora, N.; Surolia, A.; Karande, A.A. Ribosome inactivating proteins and apoptosis. FEBS Lett. 2005, 579, 1324-1331. [CrossRef]

21. Piascik, P. Fda approves fusion protein for treatment of lymphoma. J. Am. Pharm. Assoc. 1999, 39, 571-572. [CrossRef]

22. Fancher, K.M.; Lally-Montgomery, Z.C. Moxetumomab pasudotox: A first-in-class treatment for hairy cell leukemia. J. Oncol. Pharm. Pract. Official Publ. Int. Soc. Oncol. Pharm. Pract. 2019, 25, 1467-1472. [CrossRef]

23. Jen, E.Y.; Gao, X.; Li, L.; Zhuang, L.; Simpson, N.E.; Aryal, B.; Wang, R.; Przepiorka, D.; Shen, Y.L.; Leong, R.; et al. FDA Approval Summary: Tagraxofusp-erzs For Treatment of Blastic Plasmacytoid Dendritic Cell Neoplasm. Clin. Cancer Res. 2019, 26, 532-536. [CrossRef]

24. Kim, J.-S.; Jun, S.-Y.; Kim, Y.-S. Critical Issues in the Development of Immunotoxins for Anticancer Therapy. J. Pharm. Sci. 2019, 109, 104-115. [CrossRef] [PubMed]

25. De Muga, S.; Hernández, S.; Agell, L.; Salido, M.; Juanpere, N.; Lorenzo, M.; Lorente, J.A.; Serrano, S.; Lloreta, J. Molecular alterations of EGFR and PTEN in prostate cancer: Association with high-grade and advanced-stage carcinomas. Mod. Pathol. 2010, 23, 703-712. [CrossRef]

26. Di Lorenzo, G.; Tortora, G.; D'Armiento, F.P.; De Rosa, G.; Staibano, S.; Autorino, R.; D'Armiento, M.; De Laurentiis, M.; De Placido, S.; Catalano, G.; et al. Expression of epidermal growth factor receptor correlates with disease relapse and progression to androgen-independence in human prostate cancer. Clin. Cancer Res. 2002, 8, 3438-3444.

27. Schlomm, T.; Kirstein, P.; Iwers, L.; Daniel, B.; Steuber, T.; Walz, J.; Chun, F.H.; Haese, A.; Kollermann, J.; Graefen, M.; et al. Clinical Significance of Epidermal Growth Factor Receptor Protein Overexpression and Gene Copy Number Gains in Prostate Cancer. Clin. Cancer Res. 2007, 13, 6579-6584. [CrossRef]

28. Buhler, P.; Molnar, E.; Dopfer, E.P.; Wolf, P.; Gierschner, D.; Wetterauer, U.; Schamel, W.W.; Elsasser-Beile, U. Target-dependent $\mathrm{t}$-cell activation by coligation with a psma $\mathrm{x}$ cd3 diabody induces lysis of prostate cancer cells. J. Immunother. 2009, 32, 565-573. [CrossRef]

29. Bostad, M.; Kausberg, M.; Weyergang, A.; Olsen, C.E.; Berg, K.; Høgset, A.; Selbo, P.K. Light-Triggered, Efficient Cytosolic Release of IM7-Saporin Targeting the Putative Cancer Stem Cell Marker CD44 by Photochemical Internalization. Mol. Pharm. 2014, 11, 2764-2776. [CrossRef]

30. Siva, A.C.; Wild, M.A.; Kirkland, R.E.; Nolan, M.J.; Lin, B.; Maruyama, T.; Yantiri-Wernimont, F.; Frederickson, S.; Bowdish, K.S.; Xin, H. Targeting CUB Domain-Containing Protein 1 with a Monoclonal Antibody Inhibits Metastasis in a Prostate Cancer Model. Cancer Res. 2008, 68, 3759-3766. [CrossRef] [PubMed]

31. Fischer, A.; Wolf, I.; Fuchs, H.; Masilamani, A.P.; Wolf, P. Pseudomonas Exotoxin A Based Toxins Targeting Epidermal Growth Factor Receptor for the Treatment of Prostate Cancer. Toxins 2020, 12, 753. [CrossRef] [PubMed]

32. Niesen, J.; Stein, C.; Brehm, H.; Hehmann-Titt, G.; Fendel, R.; Melmer, G.; Fischer, R.; Barth, S. Novel EGFR-specific immunotoxins based on panitumumab and cetuximab show in vitro and ex vivo activity against different tumor entities. J. Cancer Res. Clin. Oncol. 2015, 141, 2079-2095. [CrossRef] [PubMed]

33. Yip, W.L.; Weyergang, A.; Berg, K.; Tønnesen, H.H.; Selbo, P.K. Targeted Delivery and Enhanced Cytotoxicity of CetuximabSaporin by Photochemical Internalization in EGFR-Positive Cancer Cells. Mol. Pharm. 2007, 4, 241-251. [CrossRef]

34. Davol, P.; Frackelton, A.R., Jr. The mitotoxin, basic fibroblast growth factor-saporin, effectively targets human prostatic carcinoma in an animal model. J. Urol. 1996, 156, 1174-1179. [CrossRef]

35. Wang, L.; Liu, B.; Schmidt, M.; Lu, Y.; Wels, W.; Fan, Z. Antitumor effect of an her2-specific antibody-toxin fusion protein on human prostate cancer cells. Prostate 2001, 47, 21-28. [CrossRef]

36. Joshi, B.H.; Leland, P.; Calvo, A.; Green, J.E.; Puri, R.K. Human Adrenomedullin Up-regulates Interleukin-13 Receptor $\alpha 2$ Chain in Prostate Cancer In vitro and In vivo: A Novel Approach to Sensitize Prostate Cancer to Anticancer Therapy. Cancer Res. 2008, 68, 9311-9317. [CrossRef]

37. Kawakami, K.; Husain, S.R.; Bright, R.K.; Puri, R.K. Gene transfer of interleukin 13 receptor $\alpha 2$ chain dramatically enhances the antitumor effect of IL-13 receptor-targeted cytotoxin in human prostate cancer xenografts. Cancer Gene Ther. 2001, 8, 861-868. [CrossRef]

38. Maini, A.; Hillman, G.; Haas, G.P.; Wang, C.Y.; Montecillo, E.; Hamzavi, F.; Pontes, J.E.; Leland, P.; Pastan, I.; Debinski, W.; et al. Interleukin-13 receptors on human prostate carcinoma cell lines represent a novel target for a chimeric protein composed of il-13 and a mutated form of pseudomonas exotoxin. J. Urol. 1997, 158, 948-953. [CrossRef] 
39. Husain, S.R.; Kawakami, K.; Kawakami, M.; Puri, R.K. Interleukin-4 receptor-targeted cytotoxin therapy of androgen-dependent and -independent prostate carcinoma in xenograft models. Mol. Cancer Ther. 2003, 2, 245-254.

40. Debinski, W.; Pastan, I. An immunotoxin with increased activity and homogeneity produced by reducing the number of lysine residues in recombinant Pseudomonas exotoxin. Bioconjugate Chem. 1994, 5, 40-46. [CrossRef]

41. Gho, Y.S.; Chae, C.B. Luteinizing hormone releasing hormone-RNase A conjugates specifically inhibit the proliferation of LHRH-receptor-positive human prostate and breast tumor cells. Mol. Cells 1999, 9, 31-36.

42. Skrepnik, N.; Zieske, A.W.; Bravo, J.C.; Gillespie, A.T.; Hunt, J.D. Recombinant oncotoxin ar209 (anti-p185erbb-2) diminishes human prostate carcinoma xenografts. J. Urol. 1999, 161, 984-989. [CrossRef]

43. Xing, Y.; Xu, K.; Li, S.; Cao, L.; Nan, Y.; Li, Q.; Li, W.; Hong, Z. A Single-Domain Antibody-Based Anti-PSMA Recombinant Immunotoxin Exhibits Specificity and Efficacy for Prostate Cancer Therapy. Int. J. Mol. Sci. 2021, 22, 5501. [CrossRef]

44. Michalska, M.; Schultze-Seemann, S.; Kuckuck, I.; Wolf, P. In Vitro Evaluation of Humanized/De-immunized Anti-PSMA Immunotoxins for the Treatment of Prostate Cancer. Anticancer. Res. 2018, 38, 61-69. [CrossRef]

45. Meng, P.; Dong, Q.-C.; Tan, G.-G.; Wen, W.-H.; Wang, H.; Zhang, G.; Wang, Y.-Z.; Jing, Y.-M.; Wang, C.; Qin, W.-J.; et al. Anti-tumor effects of a recombinant anti-prostate specific membrane antigen immunotoxin against prostate cancer cells. BMC Urol. 2017, 17, 1-7. [CrossRef] [PubMed]

46. Michalska, M.; Schultze-Seemann, S.; Bogatyreva, L.; Hauschke, D.; Wetterauer, U.; Wolf, P. In vitro and in vivo effects of a recombinant anti-PSMA immunotoxin in combination with docetaxel against prostate cancer. Oncotarget 2016, 7, 22531-22542. [CrossRef]

47. Baiz, D.; Hassan, S.; Choi, Y.A.; Flores, A.; Karpova, Y.; Yancey, D.; Pullikuth, A.; Sui, G.; Sadelain, M.; Debinski, W.; et al. Combination of the PI3K Inhibitor ZSTK474 with a PSMA-Targeted Immunotoxin Accelerates Apoptosis and Regression of Prostate Cancer. Neoplasia 2013, 15, 1172-1183, IN25-IN32. [CrossRef]

48. Zhang, F.; Shan, L.; Liu, Y.; Neville, D.; Woo, J.-H.; Chen, Y.; Korotcov, A.; Lin, S.; Huang, S.; Sridhar, R.; et al. An Anti-PSMA Bivalent Immunotoxin Exhibits Specificity and Efficacy for Prostate Cancer Imaging and Therapy. Adv. Heal. Mater. 2012, 2, 736-744. [CrossRef]

49. Bühler, P.; Wetterauer, D.; Gierschner, D.; Wetterauer, U.; Beile, U.E.; Wolf, P. Influence of structural variations on biological activity of anti-PSMA scFv and immunotoxins targeting prostate cancer. Anticancer. Res. 2010, 30, 3373-3379.

50. Kuroda, K.; Liu, H.; Kim, S.; Guo, M.; Navarro, V.; Bander, N.H. Saporin toxin-conjugated monoclonal antibody targeting prostate-specific membrane antigen has potent anticancer activity. Prostate 2010, 70, 1286-1294. [CrossRef]

51. Wolf, P.; Alt, K.; Wetterauer, D.; Bühler, P.; Gierschner, D.; Katzenwadel, A.; Wetterauer, U.; Elsässer-Beile, U. Preclinical Evaluation of a Recombinant Anti-Prostate Specific Membrane Antigen Single-Chain Immunotoxin Against Prostate Cancer. J. Immunother. 2010, 33, 262-271. [CrossRef]

52. Wolf, P.; Alt, K.; Bühler, P.; Katzenwadel, A.; Wetterauer, U.; Tacke, M.; Elsässer-Beile, U. Anti-PSMA immunotoxin as novel treatment for prostate cancer? High and specific antitumor activity on human prostate xenograft tumors in SCID mice. Prostate 2007, 68, 129-138. [CrossRef] [PubMed]

53. Wolf, P.; Gierschner, D.; Buhler, P.; Wetterauer, U.; Elsässer-Beile, U. A recombinant PSMA-specific single-chain immunotoxin has potent and selective toxicity against prostate cancer cells. Cancer Immunol. Immunother. 2006, 55, 1367-1373. [CrossRef] [PubMed]

54. Huang, X.; Bennett, M.; Thorpe, P.E. Anti-tumor effects and lack of side effects in mice of an immunotoxin directed against human and mouse prostate-specific membrane antigen. Prostate 2004, 61, 1-11. [CrossRef]

55. Fracasso, G.; Bellisola, G.; Cingarlini, S.; Castelletti, D.; Prayer-Galetti, T.; Pagano, F.; Tridente, G.; Colombatti, M. Anti-tumor effects of toxins targeted to the prostate specific membrane antigen. Prostate 2002, 53, 9-23. [CrossRef]

56. Ippoliti, R.; Ginobbi, P.; Lendaro, E.; D'Agostino, I.; Ombres, D.; Benedetti, P.A.; Brunori, M.; Citro, G. The effect of monensin and chloroquine on the endocytosis and toxicity of chimeric toxins. Cell. Mol. Life Sci. 1998, 54, 866-875. [CrossRef]

57. Jain, R.K. Delivery of molecular and cellular medicine to solid tumors. Adv. Drug Deliv. Rev. 2001, 46, 149-168. [CrossRef]

58. Belli, C.; Trapani, D.; Viale, G.; D’Amico, P.; Duso, B.A.; Della Vigna, P.; Orsi, F.; Curigliano, G. Targeting the microenvironment in solid tumors. Cancer Treat. Rev. 2018, 65, 22-32. [CrossRef] [PubMed]

59. Rogers, O.C.; Rosen, D.M.; Antony, L.; Harper, H.M.; Das, D.; Yang, X.; Minn, I.; Mease, R.C.; Pomper, M.G.; Denmeade, S.R. Targeted delivery of cytotoxic proteins to prostate cancer via conjugation to small molecule urea-based PSMA inhibitors. Sci. Rep. 2021, 11. [CrossRef]

60. Jayram, G.; Eggener, S.E. Patient selection for focal therapy of localized prostate cancer. Curr. Opin. Urol. 2009, 19, 268-273. [CrossRef] [PubMed]

61. Bos, W.V.D.; Muller, B.G.; Ahmed, H.; Bangma, C.H.; Barret, E.; Crouzet, S.; Eggener, S.E.; Gill, I.S.; Joniau, S.; Kovacs, G.; et al. Focal Therapy in Prostate Cancer: International Multidisciplinary Consensus on Trial Design. Eur. Urol. 2014, 65, 1078-1083. [CrossRef] [PubMed]

62. Ahdoot, M.; Lebastchi, A.H.; Turkbey, B.; Wood, B.; Pinto, P.A. Contemporary treatments in prostate cancer focal therapy. Curr. Opin. Oncol. 2019, 31, 200-206. [CrossRef] [PubMed]

63. Tredan, O.; Galmarini, C.M.; Patel, K.; Tannock, I.F. Drug Resistance and the Solid Tumor Microenvironment. J. Natl. Cancer Inst. 2007, 99, 1441-1454. [CrossRef]

64. Griffon-Etienne, G.; Boucher, Y.; Brekken, C.; Suit, H.D.; Jain, R.K. Taxane-induced apoptosis decompresses blood vessels and lowers interstitial fluid pressure in solid tumors: Clinical implications. Cancer Res. 1999, 59, 3776-3782. 
65. Jang, S.H.; Wientjes, M.G.; Au, J.L. Enhancement of paclitaxel delivery to solid tumors by apoptosis-inducing pretreatment: Effect of treatment schedule. J. Pharmacol. Exp. Ther. 2001, 296, 1035-1042.

66. Alzubi, J.; Dettmer-Monaco, V.; Kuehle, J.; Thorausch, N.; Seidl, M.; Taromi, S.; Schamel, W.; Zeiser, R.; Abken, H.; Cathomen, T.; et al. PSMA-Directed CAR T Cells Combined with Low-Dose Docetaxel Treatment Induce Tumor Regression in a Prostate Cancer Xenograft Model. Mol. Ther. Oncolytics 2020, 18, 226-235. [CrossRef]

67. Pyzik, M.; Sand, K.M.K.; Hubbard, J.J.; Andersen, J.T.; Sandlie, I.; Blumberg, R.S. The neonatal fc receptor (fcrn): A misnomer? Front. Immunol. 2019, 10, 1540. [CrossRef]

68. Liu, L. Pharmacokinetics of monoclonal antibodies and Fc-fusion proteins. Protein Cell 2017, 9, 15-32. [CrossRef] [PubMed]

69. Asano, R.; Hagiwara, Y.; Koyama, N.; Masakari, Y.; Orimo, R.; Arai, K.; Ogata, H.; Furumoto, S.; Umetsu, M.; Kumagai, I. Multimerization of anti-(epidermal growth factor receptor) IgG fragments induces an antitumor effect: The case for humanized 528 scFv multimers. FEBS J. 2013, 280, 4816-4826. [CrossRef] [PubMed]

70. Zheng, Z.; Okada, R.; Kobayashi, H.; Nagaya, T.; Wei, J.; Zhou, Q.; Lee, F.; Bera, T.K.; Gao, Y.; Kuhlman, W.; et al. Site-Specific PEGylation of Anti-Mesothelin Recombinant Immunotoxins Increases Half-life and Antitumor Activity. Mol. Cancer Ther. 2019, 19, 812-821. [CrossRef]

71. Elsässer-Beile, U.; Wolf, P.; Gierschner, D.; Bühler, P.; Schultze-Seemann, W.; Wetterauer, U. A new generation of monoclonal and recombinant antibodies against cell-adherent prostate specific membrane antigen for diagnostic and therapeutic targeting of prostate cancer. Prostate 2006, 66, 1359-1370. [CrossRef] [PubMed]

72. Zhou, Y.; Goenaga, A.-L.; Harms, B.D.; Zou, H.; Lou, J.; Conrad, F.; Adams, G.P.; Schoeberl, B.; Nielsen, U.B.; Marks, J.D. Impact of Intrinsic Affinity on Functional Binding and Biological Activity of EGFR Antibodies. Mol. Cancer Ther. 2012, 11, 1467-1476. [CrossRef] [PubMed]

73. Adams, G.P.; Schier, R.; McCall, A.M.; Simmons, H.H.; Horak, E.M.; Alpaugh, R.K.; Marks, J.D.; Weiner, L.M. High affinity restricts the localization and tumor penetration of single-chain $\mathrm{fv}$ antibody molecules. Cancer Res. 2001, 61, 4750-4755. [PubMed]

74. Suksanpaisan, L.; Russell, S.J.; Peng, K.W. High scfv-receptor affinity does not enhance the antitumor activity of her2-retargeted measles virus. Cancer Gene Ther. 2014, 21, 256-260. [CrossRef] [PubMed]

75. Gonzalez-Moreno, O.; Calvo, A.; Joshi, B.H.; Abasolo, I.; Leland, P.; Wang, Z.; Montuenga, L.; Puri, R.K.; Green, J.E. Gene expression profiling identifies IL-13 receptor?2 chain as a therapeutic target in prostate tumor cells overexpressing adrenomedullin. Int. J. Cancer 2004, 114, 870-878. [CrossRef]

76. Kawakami, K.; Takeshita, F.; Puri, R.K. Identification of Distinct Roles for a Dileucine and a Tyrosine Internalization Motif in the Interleukin (IL)-13 Binding Component IL-13 Receptor $\alpha 2$ Chain. J. Biol. Chem. 2001, 276, 25114-25120. [CrossRef]

77. Chen, J.; Zeng, F.; Forrester, S.J.; Eguchi, S.; Zhang, M.-Z.; Harris, R.C. Expression and Function of the Epidermal Growth Factor Receptor in Physiology and Disease. Physiol. Rev. 2016, 96, 1025-1069. [CrossRef]

78. Elsasser-Beile, U.; Buhler, P.; Wolf, P. Targeted therapies for prostate cancer against the prostate specific membrane antigen. Curr. Drug Targets 2009, 10, 118-125. [CrossRef]

79. Wolf, P.; Freudenberg, N.; Bühler, P.; Alt, K.; Schultze-Seemann, W.; Wetterauer, U.; Elsässer-Beile, U. Three conformational antibodies specific for different PSMA epitopes are promising diagnostic and therapeutic tools for prostate cancer. Prostate 2009, 70, 562-569. [CrossRef]

80. Langbein, T.; Chaussé, G.; Baum, R.P. Salivary Gland Toxicity of PSMA Radioligand Therapy: Relevance and Preventive Strategies. J. Nucl. Med. 2018, 59, 1172-1173. [CrossRef]

81. Mazor, R.; Pastan, I. Immunogenicity of Immunotoxins Containing Pseudomonas Exotoxin A: Causes, Consequences, and Mitigation. Front. Immunol. 2020, 11, 1261. [CrossRef] [PubMed]

82. Sethu, S.; Govindappa, K.; Alhaidari, M.; Pirmohamed, M.; Park, K.; Sathish, J. Immunogenicity to biologics: Mechanisms, prediction and reduction. Arch. Immunol. Ther. Exp. 2012, 60, 331-344. [CrossRef]

83. Bloem, K.; Hernández-Breijo, B.; Martínez-Feito, A.; Rispens, T. Immunogenicity of Therapeutic Antibodies: Monitoring Antidrug Antibodies in a Clinical Context. Ther. Drug Monit. 2017, 39, 327-332. [CrossRef]

84. Klee, G.G. Human Anti-Mouse Antibodies. Arch. Pathol. Lab. Med. 2000, 124, 921-923. [CrossRef]

85. Presta, L.G. Engineering of therapeutic antibodies to minimize immunogenicity and optimize function. Adv. Drug Deliv. Rev. 2006, 58, 640-656. [CrossRef]

86. Frenzel, A.; Kügler, J.; Helmsing, S.; Meier, D.; Schirrmann, T.; Hust, M.; Dübel, S. Designing Human Antibodies by Phage Display. Transfus. Med. Hemotherapy 2017, 44, 312-318. [CrossRef]

87. Cizeau, J.; Grenkow, D.M.; Brown, J.G.; Entwistle, J.; MacDonald, G.C. Engineering and biological characterization of vb6-845, an anti-epcam immunotoxin containing a t-cell epitope-depleted variant of the plant toxin bouganin. J. Immunother. 2009, 32, 574-584. [CrossRef] [PubMed]

88. Weldon, J.E.; Xiang, L.; Chertov, O.; Margulies, I.; Kreitman, R.J.; Fitzgerald, D.J.; Pastan, I. A protease-resistant immunotoxin against CD22 with greatly increased activity against CLL and diminished animal toxicity. Blood 2009, 113, 3792-3800. [CrossRef]

89. Mazor, R.; Onda, M.; Park, D.; Addissie, S.; Xiang, L.; Zhang, J.; Hassan, R.; Pastan, I. Dual B- and T-cell de-immunization of recombinant immunotoxin targeting mesothelin with high cytotoxic activity. Oncotarget 2016, 7, 29916-29926. [CrossRef]

90. Veronese, F.M.; Mero, A. The Impact of PEGylation on Biological Therapies. BioDrugs 2008, 22, 315-329. [CrossRef]

91. Zhang, P.; Sun, F.; Liu, S.; Jiang, S. Anti-PEG antibodies in the clinic: Current issues and beyond PEGylation. J. Control. Release 2016, 244, 184-193. [CrossRef] 
92. Lorberboum-Galski, H. Human toxin-based recombinant immunotoxins/chimeric proteins as a drug delivery system for targeted treatment of human diseases. Expert Opin. Drug Deliv. 2011, 8, 605-621. [CrossRef]

93. Silke, J.; Meier, P. Inhibitor of Apoptosis (IAP) Proteins-Modulators of Cell Death and Inflammation. Cold Spring Harb. Perspect. Biol. 2013, 5, a008730. [CrossRef]

94. Jordaan, S.; Akinrinmade, O.A.; Nachreiner, T.; Cremer, C.; Naran, K.; Chetty, S.; Barth, S. Updates in the Development of ImmunoRNases for the Selective Killing of Tumor Cells. Biomedicines 2018, 6, 28. [CrossRef]

95. Hlongwane, P.; Mungra, N.; Madheswaran, S.; Akinrinmade, O.A.; Chetty, S.; Barth, S. Human Granzyme B Based Targeted Cytolytic Fusion Proteins. Biomed. 2018, 6, 72. [CrossRef]

96. Fuchs, H.; Weng, A.; Gilabert-Oriol, R. Augmenting the Efficacy of Immunotoxins and Other Targeted Protein Toxins by Endosomal Escape Enhancers. Toxins 2016, 8, 200. [CrossRef]

97. Fuchs, H.; Niesler, N.; Trautner, A.; Sama, S.; Jerz, G.; Panjideh, H.; Weng, A. Glycosylated Triterpenoids as Endosomal Escape Enhancers in Targeted Tumor Therapies. Biomedicines 2017, 5, 14. [CrossRef] [PubMed]

98. Jerjes, W.; Theodossiou, T.A.; Hirschberg, H.; Høgset, A.; Weyergang, A.; Selbo, P.K.; Hamdoon, Z.; Hopper, C.; Berg, K. Photochemical Internalization for Intracellular Drug Delivery. From Basic Mechanisms to Clinical Research. J. Clin. Med. 2020, 9, 528. [CrossRef]

99. Dieffenbach, M.; Pastan, I. Mechanisms of Resistance to Immunotoxins Containing Pseudomonas Exotoxin A in Cancer Therapy. Biomolecules 2020, 10, 979. [CrossRef]

100. Krajewska, M.; Krajewski, S.; Epstein, J.I.; Shabaik, A.; Sauvageot, J.; Song, K.; Kitada, S.; Reed, J.C. Immunohistochemical analysis of bcl-2, bax, bcl-X, and mcl-1 expression in prostate cancers. Am. J. Pathol. 1996, 148, 1567-1576.

101. Yoshino, T.; Shiina, H.; Urakami, S.; Kikuno, N.; Yoneda, T.; Shigeno, K.; Igawa, M. Bcl-2 Expression as a Predictive Marker of Hormone-Refractory Prostate Cancer Treated with Taxane-Based Chemotherapy. Clin. Cancer Res. 2006, 12, 6116-6124. [CrossRef] [PubMed] 